\title{
INTERNAL DISEASE
}

UDC 615.015.14

\section{Bioavailability Study of Recombinant Plasmid DNA Nerve Growth Factor after Intramuscular Injection by Electroporation}

\author{
V. V.Shilov ${ }^{1,4}$, M. A. Yudin ${ }^{1,3}$, N. G. Vengerovich ${ }^{2,3}$, \\ T. V.Shcherbakov ${ }^{4}$, A.S. Bogacheva ${ }^{1}$ \\ ${ }^{1}$ North-Western State Medical University named after I. I. Mechnikov, \\ 47, Piskarevskii pr., St. Petersburg, 195067, Russian Federation \\ ${ }^{2}$ Saint Petersburg State Chemical Pharmaceutical Academy (SPCPA), \\ 14a, ul. Professora Popova, St. Petersburg, 197376, Russian Federation \\ ${ }^{3}$ Federal State Budgetary Institution "State Research Testing Institute of Military Medicine" \\ of the Ministry of Defense of Russian Federation, \\ 4, Lesoparkovaya ul., St. Petersburg, 195043, Russian Federation \\ ${ }^{4}$ North-West Public Health Research Center Rights Protection \\ and Human Wellbeing, \\ 4, 2-ya Sovetskaya ul., 191036, St. Petersburg, Russian Federation
}

For citation: Shilov V.V., Yudin M.A., Vengerovich N.G., Shcherbakov T.V., Bogacheva A.S. Bioavailability Study of Recombinant Plasmid DNA Nerve Growth Factor after Intramuscular Injection by Electroporation. Vestnik of Saint Petersburg University. Medicine, 2019, vol. 14, issue 1, pp. 8996. https://doi.org/10.21638/spbu11.2019.201

Comparative analysis of plasmid DNA delivery into cells efficiency (with effective agent concentration $250 \mu \mathrm{g} / \mathrm{kg}$ ), ensuring accumulation of nerve growth factor (NGF) after intramuscular injection and intramuscular administration using electroporation method on rats was performed. Application of electroporation method ensured over 4 times increase of DNA plasmid concentration in muscle tissue within the first hour after its injection and increased the duration of its determination. Higher bioavailability parameters were confirmed by 3 times increase in gene expression level, encoding NGF accumulation and 3 times increase in concentration of the target NGF protein in blood plasma. The results obtained allow us to recommend this method for introduction of NGF plDNA in its biological activity and effectiveness in models of nerve damage investigation.

Keywords: plasmid DNA, pharmacokinetics, gene expression, bioavailability, electroporation.

(c) Санкт-Петербургский государственный университет, 2019 


\section{Introduction}

Steady growth of neurodegenerative disease incidence in overall structure of nervous system pathology is observed today [1]. Clinically significant cases of severe decompensation of nervous system with the progression of Alzheimer and Parkinson diseases become widespread in active working age people $[2 ; 3]$.

High probability of peripheral polyneuropathies development is especially acute in relation to workers of occupationally harmful industries, such as facilities for production and storage of organophosphorous compounds (OPC) or agricultural production.

The loss of function of the nerves and/or areas of the brain is accompanied by decrease in the quality of life, and the most severe forms of damage result in disability of patients.

Pharmacological correction of toxic polyneuropathy and encephalopathy involves prescription of drugs that improve neuronal conductivity, microcirculation, energoplastic and metabotropic processes that produce pathogenetic and symptomatic effect. However, even timely start of treatment and use of modern medicines sometimes provides only retardation of disease progression [4]. It is known that development of organophosphate peripheral neuropathies is based on neuron and neuronal microenvironment degeneration processes, demyelination of nerve conductors, death of Schwann cells, multiple axonopathies with the release of molecules with antigenic properties into extracellular space [5]. These changes result in development of local inflammation and an autoimmune process with a transition to a sluggish, progressive form and replacement of nervous tissue in lesions by connective tissue [6]. Necessary condition for neuronal tissue regeneration after injury (for example, axotomy) is neurotrophins, neuropoietic cytokines, insulin-like growth factor and glial cell-derived neurotrophic factor expression.

It seems reasonable to use genetic make-ups on the basis of DNA expressing nerve growth factor (NGF) for treatment of nervous system diseases associated with organic disturbances (lesions) of nerve conductors [7]. Its neuroprotective effect in Alzheimer's disease has been shown in clinical study conditions. Thus, adeno-associated viral vector, used for encoding human NGF (AAV2-NGF) to Meinert's basal nucleus, ensured safety and efficiency of treatment in case of patients with mild disease [8]. High efficiency of NGF application was demonstrated for spinal cord injury, especially when combined with neurotrophic and neurotrophin-3 factor [9].

NGF provides growth, differentiation and restoration of axons and dendrites, formation of neurons cytoskeleton, exocytosis and functioning of synapses, neuroendocrine and immune systems [10]. This factor prevents cell death and stimulates the functional activity of basal membrane in cholinergic neurons, improves Schwann cells migration, thereby preventing or retarding degenerative processes of the nervous tissue inherent in Alzheimer's disease and toxic polyneuropathy. Due to high molecular weight and charge, NGF has a low ability to overcome blood-brain barrier, which requires development of effective means of its delivery [11].

More convincing data were obtained when using trophic growth factors, including those which were delivered by means of plasmid technology with subsequent expression in the body. Plasmids are small double-stranded circular extrachromosomal DNA molecules which are present in bacterial cells and which have become the most common genetic engineering material. To ensure "targeted delivery" of plasmid-based DNA constructs, it 
seems necessary to use transfection enhancement methods. It is known that DNA plasmid penetration into a transfected cell occurs by means of endocytosis (phagocytosis, pinocytosis, receptor-mediated endocytosis). However, the process of endocytosis inside muscle fibers themselves is almost impossible; therefore, DNA plasmids are concentrated mainly in the cells of muscle environment.

One of the major disadvantages of plasmid DNA (plDNA) application is low efficiency of its transfection and expression of the target protein, which jointly characterize bioavailability of genetic construct. To obtain the target bioavailability when extrapolating a potential therapeutic effect in humans after injection of genetic plDNA-based agents, it is necessary to use transfection increase methods, among which physical (electroporation) transfection is considered to be high-demand one [12].

Objective of the study - the purpose of the study is to study the dynamics of NGF plDNA concentration and the level of its expression after intramuscular injection to animals using electroporation method.

Materials and methods of the study - experiments were performed on 500 white outbred male rats weighing 180-220 g, supplied by "Rappolovo" breeding station (Leningrad region). The animals were kept in standard vivarium conditions at normal diet with free access to water. Previously, they all were in quarantine for at least 14 days.

Sample of plDNA recombinant encoding NGF production was used as a solution (manufactured by OJSC "ATG Service Gene", Russia), presenting itself as rat NGF gene expression vector under control of early cytomegalovirus gene promoter. PIDNA was injected intramuscularly conventionally and/or using electroporation method. For electroporation was used NEPA21 instrument (Nepagen, Japan). Before performing this technique, animals were anesthetized with a $5 \%$ solution of sevoflurane by means of hardware-software complex for artificial lung ventilation: "Single channel anesthesia system", Kent Scientific Corporation (USA). PIDNA was injected to rats in a volume of $0.1 \mathrm{ml}$ per $1 \mathrm{~kg}$ of animal body weight at a dose of $250 \mu \mathrm{g} / \mathrm{kg}$. Preparation dose was administered in three successive injections into the right tibial muscle at a distance of 2-3 $\mathrm{mm}$ from each other. Immediately after the introduction of the plasmid, an electrical discharge was applied with the following parameters:

- pore forming effect (voltage $-250 \mathrm{~V}$, pulse duration $-8 \mathrm{~ms}$, pulse interval $50 \mathrm{~ms}$, number of pulses -2 , attenuation $-40 \%$, without reversing electrodes the polarity $(+))$;

- transfer effect (voltage $-50 \mathrm{~V}$, pulse duration $-50 \mathrm{~ms}$, pulse interval $-50 \mathrm{~ms}$, number of pulses -9 , attenuation $-40 \%$, with reversing electrodes the polarity $(+/-))$.

Analysis of plDNA concentration was carried out using equation, which allows to calculate DNA and RNA amount in blood and muscle tissue taken from animals before (intact indicators) and 1, 2, 4, 6, 8, 24 hours after its intramuscular injection. 10-30 mg of tissue homogenate or $250 \mu \mathrm{L}$ of whole blood were used for the analysis. Tissue samples were homogenized using a homogenizer or by grinding in a mortar with micronized quartz sand.

DNA extraction was performed in accordance with instructions for DNA-sorb B kit. RNA extraction from tissues was performed using the TRI Reagent kit (manufactured by Sigma) according to manufacturer's instructions. The cDNA synthesis was performed 
using the Revert Aid ${ }^{\oplus}$ First Strand cDNA Synthesis Kit manufactured by "Fermentas". To measure the relative content of mRNA, RealTime PCR with SYBR GREEN (SYBR Green Supermix (Bio-Rad)) was used. All the samples were normalized to the level of glyceraldehyde-3-phosphate dihydrogenase (GAPDH) gene expression. The reaction was performed using an IQ5 ("Bio-Rad") thermal cycler, the data were analyzed using the enclosed software.

The following parameters obtained using the Thermo Kinetica 5.1 program (ThermoElectronCorporation, USA) were used to estimate pharmacokinetic properties:

- AUCtot $\left(\mathrm{ng} / \mathrm{ml}{ }^{*} \mathrm{~min}\right)$ - the area under the concentration-time curve. It is determined by diagram construction in "concentration-time" coordinates, the area under the curve being calculated;

- total clearance $(\mathrm{Cl}, \mathrm{ml} / \mathrm{min})$ - determines the amount of test tissue released from the substance per unit of time and calculated as the ratio of substance dose (D) to AUCtot;

- MRT average retention time in test tissue;

- stationary distribution volume (Vss, l) - proportionality coefficient between substance concentration in test chamber and its body amount. It reflects substance distribution intensity between test chambers;

- half-life (T1/2, min) - a period of time during which substance's concentration reduces by half;

- absorption rate constant is exponent characterizing the rate at which substance enters bloodstream from injection site.

Efficiency of plDNA application was studied using experimental model of toxic neuropathy caused by subacute (daily for 3 days) intragastric intoxication of rats by malathion at dose equals 0.5 LD50. Indirect electroneuromyography (ENMG) method was used to estimate extent of damage caused to the peripheral nervous system. Motor response threshold $(\mathrm{mA})$, amplitude $(\mathrm{mV})$, area under the curve $\left(\mathrm{mV}^{*} \mathrm{~ms}\right)$ and $\mathrm{M}$ response duration (ms) were determined [13]. Parameters were registered in dynamics in $1,2,3$ weeks after toxicant injections.

Statistical analysis was carried out using the Statistica 10 program. Calculations of central tendencies and dispersion measures were carried out by common statistical methods. Normalcy distribution verification of actual data was performed using the Shapiro Wilk criterion. Mann - Whitney, Wilcoxon and Kruskal - Wallis non-parametric criteria were used to compare mean values and to identify significant differences. Differences were considered statistically significant at $\mathrm{p}<0.05$.

\section{Study Results and Discussion}

The efficiency of plasmid DNA use is determined by its transfection degree and transposition near the cell nucleus, and kinetics of presence in the body was determined by endogenic DNA-ase effect immunity. The bioavailability of recombinant NGF plDNA was assessed by parameters of DNA content kinetics in quadriceps muscle tissue (injection site) and in rat blood, as well as by relative level of expression and specific protein accumulation over time. Comparative analysis of DNA concentration in muscle tissue to assess 


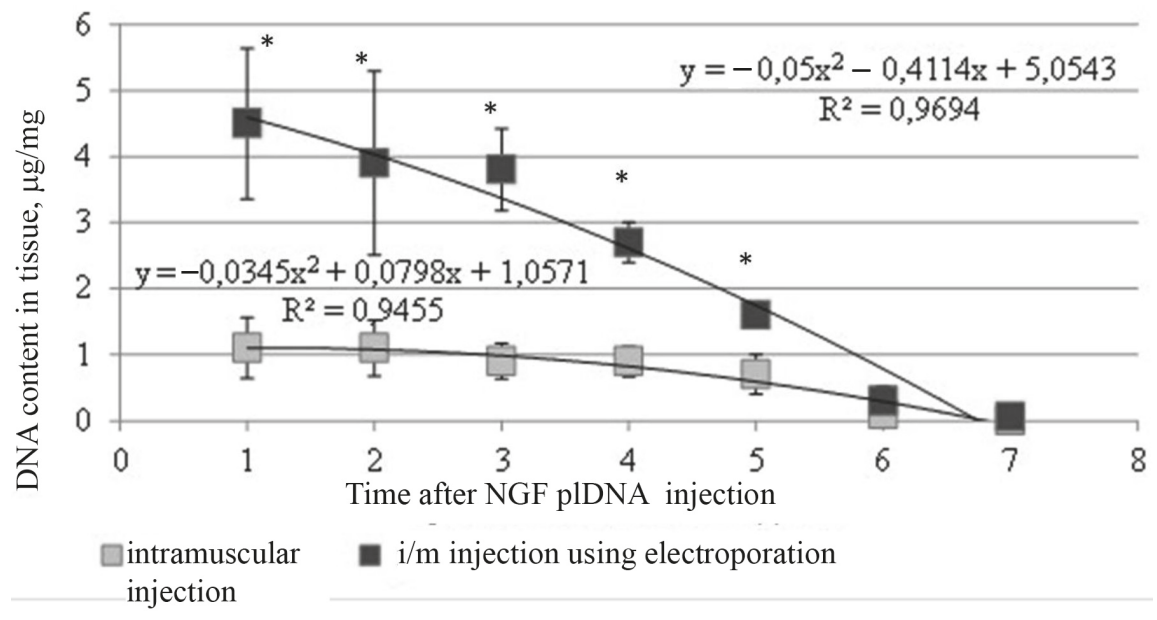

Fig. Comparative analysis of the DNA concentration in rat muscle tissue after $\mathrm{i} / \mathrm{m}$ injection and $\mathrm{i} / \mathrm{m}$ injection using the method of electroporation of recombinant NGF plDNA at a dose of $250 \mu \mathrm{g} / \mathrm{kg}, \mathrm{n}=10$

the efficiency of electroporation aimed to increase bioavailability of recombinant NGF plDNA was performed (Fig.).

One hour after $\mathrm{i} / \mathrm{m}$ injection of recombinant NGF plDNA to rats, maximum concentration of DNA in blood was observed: $4.5 \pm 0.47 \mu \mathrm{g} / \mathrm{ml}$. DNA concentration in muscle at the same period was $1.1 \pm 0.46 \mu \mathrm{g} / \mathrm{mg}$ tissue. Later (24 hours) DNA in blood was observed in trace amounts.

The data shown in Figure reliably confirm higher bioavailability indices when using the electroporation method. Estimated pharmacokinetics data of recombinant NGF plDNA using electroporation are shown in Table 1.

Table 1. Pharmacokinetic parameters of DNA in blood and quadriceps muscle of rats after intramuscular injection and intramuscular injection using the method of electroporation of recombinant NGF plDNA at dose $250 \mathrm{mg} / \mathrm{kg}(\mathrm{n}=10, \mathrm{M} \pm \mathrm{SD})$

\begin{tabular}{|c|c|c|c|c|}
\hline \multirow{2}{*}{ Parameters } & \multicolumn{2}{|c|}{ Blood } & \multicolumn{2}{c|}{ Muscle } \\
\cline { 2 - 5 } & $\begin{array}{c}\text { without } \\
\text { electroporation }\end{array}$ & $\begin{array}{c}\text { with } \\
\text { electroporation }\end{array}$ & $\begin{array}{c}\text { without } \\
\text { electroporation }\end{array}$ & $\begin{array}{c}\text { with } \\
\text { electroporation }\end{array}$ \\
\hline AUCtot, $\mathrm{h}^{*} \mu \mathrm{g} / \mathrm{ml}$ & $5,6 \pm 1,12$ & $3,9 \pm 1,21^{*}$ & $12,8 \pm 3,21$ & $39 \pm 9,66^{*}$ \\
\hline $\mathrm{T} 1 / 2, \mathrm{~h}$ & $2,8 \pm 0,76$ & $3,3 \pm 1,01$ & $5,7 \pm 1,8$ & $5,0 \pm 1,65$ \\
\hline MRT, h & $4,5 \pm 0,96$ & $5,0 \pm 1,32$ & $9,5 \pm 2,1$ & $8,2 \pm 2,31$ \\
\hline $\mathrm{Cl}, \mathrm{ml}-1$ & $35,5 \pm 10,4$ & $51,4 \pm 12,3^{*}$ & $15,6 \pm 3,76$ & $5,1 \pm 1,7^{*}$ \\
\hline $\mathrm{Vss}, \mathrm{ml}$ & $160 \pm 35$ & $257 \pm 87$ & $149 \pm 34,2$ & $42 \pm 8,93^{*}$ \\
\hline Kel, h-1 & $0,25 \pm 0,05$ & $0,21 \pm 0,04$ & $0,12 \pm 0,03$ & $0,14 \pm 0,02$ \\
\hline
\end{tabular}

N o t e: ${ }^{*}$ - differences related to "without electroporation" group are statistically significant at $p<0,05$. 
Obtained data confirms that electroporation method improves DNA penetration in muscle (target) tissue and, as a result, reduces the amount of sample that penetrates in blood from the injection site. The ratio of the area under the pharmacokinetic curve in muscle to the area in blood using electroporation constitutes 39, without electroporation - 12.8. Data from different pharmacokinetics of recombinant plDNA were confirmed by obtained results of relative level of RNA expression (Table 2).

Table 2. Dynamics of the relative expression level in rat muscle tissue after $\mathrm{i} / \mathrm{m}$ injection and $\mathrm{i} / \mathrm{m}$ injection using electroporation method of recombinant NGF plDNA at a dose of $250 \mu \mathrm{g} / \mathrm{kg}$ $(\mathrm{n}=10, \mathrm{M} \pm \mathrm{SD})$

\begin{tabular}{|c|c|c|c|c|}
\hline \multirow{3}{*}{$\begin{array}{c}\text { Time of } \\
\text { studying } \\
\text { biomaterial, } \\
\mathrm{h}\end{array}$} & \multicolumn{4}{|c|}{ RNA concentration } \\
\hline & \multicolumn{2}{|c|}{$\mathrm{i} / \mathrm{m}$ injection } & \multicolumn{2}{|c|}{$\begin{array}{l}\mathrm{i} / \mathrm{m} \text { injection using electroporation } \\
\text { method }\end{array}$} \\
\hline & Positive tests & $\begin{array}{c}\text { Average RNA } \\
\text { concentration, } \\
\text { conventional units }\end{array}$ & Positive tests & $\begin{array}{c}\text { Average RNA } \\
\text { concentration, } \\
\text { conventional units }\end{array}$ \\
\hline 1 & $8 / 8$ & $13,4 \pm 7,07$ & $8 / 8$ & $29,6 \pm 10,67$ \\
\hline 2 & $8 / 8$ & $28,1 \pm 18,59$ & $8 / 8$ & $152,5 \pm 12,9^{*}$ \\
\hline 4 & $8 / 8$ & $22,63 \pm 8,57$ & $8 / 8$ & $149,3 \pm 21,03^{\star}$ \\
\hline 6 & $8 / 8$ & $20,9 \pm 5,43$ & $8 / 8$ & $83,4 \pm 9,92^{*}$ \\
\hline 8 & $8 / 8$ & $17,0 \pm 2,75$ & $8 / 8$ & $56,8 \pm 9,64$ \\
\hline 24 & $7 / 8$ & $7,77 \pm 5,65$ & $8 / 8$ & $18,9 \pm 2,86$ \\
\hline
\end{tabular}

N o t e: ${ }^{\star}$ - differences between groups are statistically significant at $\mathrm{p}<0,05$.

In comparative analysis of this indicator after 24 hours the differences between groups reached 3 times values, which evidenced a longer presence of target DNA inside the cell and, as a result, a longer duration of transcription processes. A higher level of transfection of recombinant NGF plDNA using electroporation was proved by concentration of a specific protein (Table 3 ).

Table 3. Concentration of NGF $(\mathrm{pg} / \mathrm{ml})$ in rat blood plasma after $\mathrm{i} / \mathrm{m}$ injection and $\mathrm{i} / \mathrm{m}$ injection using electroporation method of recombinant NGF plasmid DNA at a dose of $250 \mu \mathrm{g} / \mathrm{kg}$ at different observation times $(n=10, M \pm S D)$

\begin{tabular}{|l|c|c|c|}
\hline \multirow{2}{*}{ Group } & \multicolumn{3}{|c|}{ Observation time, $\mathbf{~}$} \\
\cline { 2 - 4 } & 4 & $\mathbf{8}$ & $\mathbf{2 4}$ \\
\hline Control (physical solution) & $0 \pm 0$ & $0 \pm 0$ & $0 \pm 0$ \\
\hline NGF plDNA i/m & $10,4 \pm 3,96^{*}$ & $5,2 \pm 0,98^{\star}$ & $0,1 \pm 0,09$ \\
\hline NGF plDNA i/m with electroporation & $28,0 \pm 8,97^{\star \Delta}$ & $17,4 \pm 5,46^{* \Delta}$ & $0,5 \pm 0,32$ \\
\hline
\end{tabular}

$\mathrm{N}$ o t e s: 1$)^{\star}$ — differences from control group are statistically significant at $\left.\mathrm{p}<0,05 ; 2\right)^{\Delta}$ — differences between recombinant NGF plDNA groups are statistically significant at $\mathrm{p}<0,05$. 
So in course of studying this indicator in the period of maximum level of relative expression ( $4 \mathrm{~h}$ ), high (more than 3 times) indicators were reported when using electroporation method in comparison with $\mathrm{i} / \mathrm{m}$ injection of recombinant NGF plDNA.

Application of electroporation ensured an earlier improvement in ENMG parameters (Table 4).

Table 4. Dependence of neuromuscular conduction disorders after intragastric injection of malathion at a dose of $0.5 \mathrm{LD} 50$ and intramuscular injection of NGF RPD at a dose of $250 \mu \mathrm{g} / \mathrm{kg}$ using the electroporation method $(\mathrm{M} \pm \mathrm{mM}, \mathrm{n}=8)$

\begin{tabular}{|c|c|c|c|c|c|}
\hline \multirow{2}{*}{$\begin{array}{c}\text { One day after } \\
\text { the intoxication } \\
\text { moment }\end{array}$} & \multicolumn{5}{|c|}{ Electroneuromyography parameters } \\
\hline & $\begin{array}{c}\text { Nerve } \\
\text { irritation } \\
\text { threshold, mA }\end{array}$ & $\begin{array}{c}\text { Maximum } \\
\text { M-response, MA }\end{array}$ & $\begin{array}{c}\text { M-response } \\
\text { amplitude, } \mathrm{MV}\end{array}$ & $\begin{array}{c}\text { M-response } \\
\text { area, } M V^{\star} \text { Msec }\end{array}$ & $\begin{array}{c}\text { M-response } \\
\text { duration, msec }\end{array}$ \\
\hline \multicolumn{6}{|c|}{ Control of intoxication } \\
\hline Background & $\begin{array}{l}0,6 \pm 0,01 \\
\quad(0 \pm 8)\end{array}$ & $\begin{array}{l}1,8 \pm 0,01 \\
(0 \pm 8)\end{array}$ & $\begin{array}{l}25,5 \pm 0,11 \\
\quad(0 \pm 8)\end{array}$ & $\begin{array}{l}24,2 \pm 0,09 \\
\quad(0 \pm 8)\end{array}$ & $\begin{array}{l}1,9 \pm 0,02 \\
(0 \pm 8)\end{array}$ \\
\hline $14^{\text {th }}$ day & $\begin{array}{l}0,7 \pm 0,01 \\
(42 \pm 15)^{\star}\end{array}$ & $\begin{array}{l}1,7 \pm 0,02 \\
(50 \pm 15)^{\star}\end{array}$ & $\begin{array}{c}23,5 \pm 0,1 \\
(66 \pm 15)^{\star *}\end{array}$ & $\begin{array}{l}27,2 \pm 0,28 \\
(58 \pm 15)^{\star *}\end{array}$ & $\begin{array}{c}2 \pm 0,03 \\
(42 \pm 15)^{*}\end{array}$ \\
\hline $21^{\text {st }}$ day & $\begin{array}{l}0,7 \pm 0,01 \\
(58 \pm 15)^{\star}\end{array}$ & $\begin{array}{l}1,6 \pm 0,03 \\
(50 \pm 15)^{\star}\end{array}$ & $\begin{array}{c}23 \pm 0,13 \\
(75 \pm 13)^{\star * *}\end{array}$ & $\begin{array}{c}28 \pm 0,31 \\
(66 \pm 15)^{* *}\end{array}$ & $\begin{array}{l}2,1 \pm 0,02 \\
(50 \pm 15)^{\star}\end{array}$ \\
\hline $28^{\text {th }}$ day & $\begin{array}{c}0,7 \pm 0,02 \\
(66 \pm 15)^{* *}\end{array}$ & $\begin{array}{l}1,6 \pm 0,02 \\
(66 \pm 15)^{\star *}\end{array}$ & $\begin{array}{c}22,5 \pm 0,09 \\
(75 \pm 13)^{\star * *}\end{array}$ & $\begin{array}{l}28,4 \pm 0,48 \\
(66 \pm 15)^{\star *}\end{array}$ & $\begin{array}{c}2,2 \pm 0,02 \\
(58 \pm 15)^{\star *}\end{array}$ \\
\hline \multicolumn{6}{|c|}{ Experiment 1 (i/m injection of NGF RPD) } \\
\hline Background & $\begin{array}{l}0,6 \pm 0,01 \\
\quad(0 \pm 8)\end{array}$ & $\begin{array}{l}1,8 \pm 0,01 \\
(0 \pm 8)\end{array}$ & $\begin{array}{l}25,5 \pm 0,11 \\
\quad(0 \pm 8)\end{array}$ & $\begin{array}{l}24,2 \pm 0,09 \\
\quad(0 \pm 8)\end{array}$ & $\begin{array}{c}1,8 \pm 0,02 \\
(0 \pm 8)\end{array}$ \\
\hline $14^{\text {th }}$ day & $\begin{array}{l}0,7 \pm 0,01 \\
(42 \pm 15)^{\star}\end{array}$ & $\begin{array}{l}1,6 \pm 0,02 \\
(50 \pm 15)^{\star}\end{array}$ & $\begin{array}{l}23,4 \pm 0,1 \\
(42 \pm 15)^{\star}\end{array}$ & $\begin{array}{c}29,2 \pm 0,28 \\
(50 \pm 15)^{*}\end{array}$ & $\begin{array}{l}2,2 \pm 0,03 \\
(50 \pm 15)^{*}\end{array}$ \\
\hline $21^{\text {st }}$ day & $\begin{array}{l}0,7 \pm 0,01 \\
(33 \pm 15)\end{array}$ & $\begin{array}{l}1,7 \pm 0,03 \\
(42 \pm 15)^{\star}\end{array}$ & $\begin{array}{c}24,5 \pm 0,13 \\
(25 \pm 13)\end{array}$ & $\begin{array}{c}26,6 \pm 0,31 \\
(33 \pm 15)\end{array}$ & $\begin{array}{l}2,1 \pm 0,02 \\
(33 \pm 15)\end{array}$ \\
\hline $8^{\text {th }}$ day & $\begin{array}{c}0,6 \pm 0,02^{\Delta} \\
\left(25 \pm 13^{\Delta}\right)\end{array}$ & $\begin{array}{c}1,8 \pm 0,02^{\Delta} \\
(33 \pm 15)\end{array}$ & $\begin{array}{c}25,1 \pm 0,09 \\
\left(25 \pm 13^{\Delta}\right)\end{array}$ & $\begin{array}{c}24,8 \pm 0,48^{\Delta} \\
(25 \pm 13 \Delta)\end{array}$ & $\begin{array}{l}1,9 \pm 0,02^{\Delta} \\
\left(17 \pm 11^{\Delta}\right)\end{array}$ \\
\hline \multicolumn{6}{|c|}{ Experiment 2 (i/m injection of NGF RPD using electroporation method) } \\
\hline Background & $\begin{array}{c}0,6 \pm 0,02 \\
(0 \pm 8)\end{array}$ & $\begin{array}{c}1,8 \pm 0,02 \\
(0 \pm 8)\end{array}$ & $\begin{array}{c}25,8 \pm 0,12 \\
\quad(0 \pm 8)\end{array}$ & $\begin{array}{l}25,1 \pm 0,29 \\
\quad(0 \pm 8)\end{array}$ & $\begin{array}{c}1,9 \pm 0,02 \\
(0 \pm 8)\end{array}$ \\
\hline $14^{\text {th }}$ day & $\begin{array}{c}0,7 \pm 0,02 \\
(33 \pm 15)\end{array}$ & $\begin{array}{l}1,7 \pm 0,04 \\
(42 \pm 15)^{*}\end{array}$ & $\begin{array}{l}24,6 \pm 0,1 \\
(42 \pm 15)^{*}\end{array}$ & $\begin{array}{c}26,1 \pm 0,37 \\
(33 \pm 15)\end{array}$ & $\begin{array}{c}2,1 \pm 0,01 \\
(33 \pm 15)\end{array}$ \\
\hline $21^{\text {st }}$ day & $\begin{array}{c}0,6 \pm 0,02^{\Delta} \\
(25 \pm 13)\end{array}$ & $\begin{array}{c}1,8 \pm 0,02 \\
(33 \pm 15)\end{array}$ & $\begin{array}{c}25,2 \pm 0,13^{\Delta} \\
\left(25 \pm 13^{\Delta}\right)\end{array}$ & $\begin{array}{c}25,7 \pm 0,38^{\Delta} \\
\left(17 \pm 11^{\Delta}\right)\end{array}$ & $\begin{array}{c}2,0 \pm 0,01 \\
(25 \pm 13)\end{array}$ \\
\hline $28^{\text {th }}$ day & $\begin{array}{l}0,7 \pm 0,01 \\
\left(17 \pm 11^{\Delta}\right)\end{array}$ & $\begin{array}{l}1,8 \pm 0,01 \\
\left(25 \pm 13^{\Delta}\right)\end{array}$ & $\begin{array}{c}25,6 \pm 0,09^{\Delta} \\
\left(17 \pm 11^{\Delta}\right)\end{array}$ & $\begin{array}{c}25,2 \pm 0,44 \\
\left(17 \pm 11^{\Delta}\right)\end{array}$ & $\begin{array}{l}1,9 \pm 0,02 \\
\left(17 \pm 11^{\Delta}\right)\end{array}$ \\
\hline
\end{tabular}

Note: 1) incidence of animals with the parameter deviation as compared to total number of animals is shown in brackets; 2$)^{*}$ - differences in respect to the background are significant at $\left.\mathrm{p} \geq 0.05 ; 3\right){ }^{* *}$ — differences in respect to the background are significant at $\mathrm{p} \leq 0.01 ; 4){ }^{* \star *}$ — differences in respect to the background are significant at $\mathrm{p} \leq 0.001$; 5) ${ }^{\Delta}$ — differences in respect to the control are significant at $\mathrm{p} \leq 0.05$; 
Restoration of neuromuscular conduction parameters in the group with isolated intramuscular injection was slower. By the 14th day, according to such parameters as maximum M-response and amplitude of the M-response, neuromuscular conduction disorders were observed in a half of the animals in this group. The partial restoration of ENMG parameters was observed by the $21^{\text {st }}$ day, however, by this time the number of animals with the parameter deviation from the intra species standard was greater than in the group where electroporation method was used.

Recombinant plasmids DNA NGF reliably prevent ENMG disorder development after subacute poisoning by malathion in dose equals $0.5 \mathrm{LD} 50$. Application of electroporation method enables to achieve ENMG parameters growth by the 14th day after intoxication. Our findings allow considering the electroporation method to be a promising approach for the delivery of plasmid DNA encoding the accumulation of nerve growth factor for prevention of peripheral neuropathy.

Thereby, in course of this study, appropriateness of electroporation method in increase of bioavailability and effectiveness of plasmid DNA encoding nerve growth factor was justified.

\section{Conclusion}

1. Electroporation method, due to increase of bioavailability by 1.5 times, as well as relative level of expression of gene encoding NGF production by 3 times, and 3 times increase in concentration of target NGF protein in blood plasma, significantly increases efficiency of plDNA activity.

2. Obtained results enable us to recommend electroporation method for the injection of NGF plDNA for investigation its biological activity and efficiency in simulated nerve damages.

\section{References}

1. Chen J. Functional MRI of brain physiology in aging and regenerative diseases. Neuroimage, 2018, no. 1 , pp. 1-17.

2. Besser L., Mock C., Teylan M. Differences in cognitive impairment in primary age-related Tauopathy versus Alzheimer Disease. J. of Neuropathology, 2019, no. 1, pp. 1-10.

3. Shu L., Zhay Y., Sun Q. A comprehensive analysis in population differences in LRRK2 variant distribution in Parkinson's Disease. Front. Aging Neurosci., 2019, vol. 11, pp. 1-11.

4. Rajabally Y., Afzal S. Clinical and economic comparison of an individualised immunoglobulin protocol vs. standard dosing for chronic inflammatory demyelinating polyneuropathy. J. of Neurology, 2019, vol. 266, no. 2, pp. 10-17.

5. Chepur S. V. Delayed organophosphorus neuropathies: prevention and treatment. Toxicological Vestn., 2010, no. 3, pp. 42-43.

6. Dalakas M.C. Pathogenesis of immune-mediated neuropathies. Biochim. Biophys. Acta, 2015, vol. 1852, no. 4, pp. 658-666.

7. Sung K., Yang W., Wu, C. Uncoupling neurotrophic function from nociception of nerve growth factor: what can be learned from a rare human disease? Neural. Regen. Res., 2019, vol. 14, no. 4, pp. 1-14.

8. Tuszynski M.H., Yang J.H., Barba D. et al. Nerve Growth Factor Gene Therapy: Activation of Neuronal Responses in Alzheimer Disease. JAMA Neurol, 2015, vol. 72, no. 10, pp. 1139-1147.

9. Du J., Chen H., Qing L. Biomimetic neural scaffolds: a crucial step towards optimal peripheral nerve regeneration. Biometr. Sci., 2018, vol. 6, pp. 1299-1311.

10. Voronova A.D., Stepanova O.V., Chadin A.V. et al. The Cell Therapy in Traumatic Spinal Cord Injury. Vestn. Ross. Akad. Med. Nauk, 2016, vol. 71, no. 6, pp. 420-426. 
11. Wong A.W., Yeung J., Payne S.C. et al. Neurite outgrowth in normal and injured primary sensory neurons reveals different regulation by nerve growth factor (NGF) and artemin. Mol. Cell Neurosci., 2015 , vol. 65 , pp. $125-134$.

12. Ruzgus P., Jakutaviciate M., Chopra S. Enhancement of drug electrotransfer by extracellular plasmid DNA. Arch. Biochem. Biophys., 2018, pp. 1-5.

13. Nikolaev S.G. Workshop on Clinical Electromyography: Second Edition, revised and updated. Ivanovo: Ivan. State medical academy, 2003, 264 p.

Received: March 18, 2019

Accepted: June 17, 2019

Authors'information:

Viktor V.Shilov - Dr. Sci. in toxicology, Professor; vshilov@inbox.ru

Mikhail A. Yudin - Dr. Sci. in pharmacy

Nikolai G. Vengerovich - Dr. Sci. in pharmacy

Taras V.Shcherbakov - Researcher

Aleksandra S. Bogacheva - PhD 